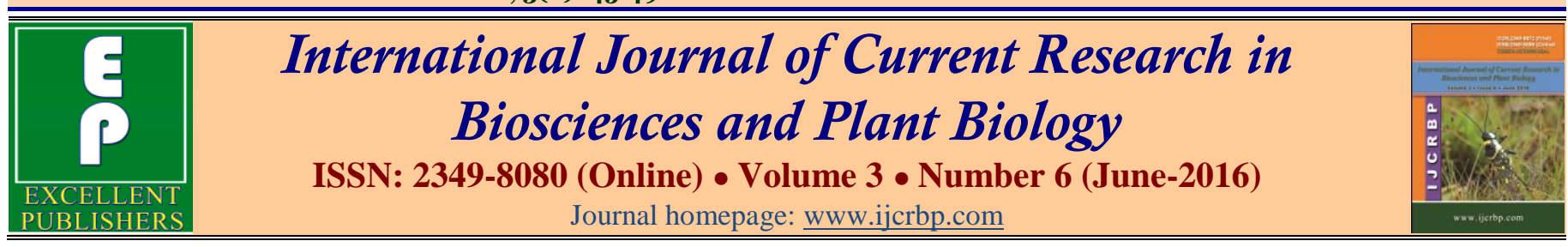

\title{
Liver Enzymes and Lipid Activities in Response to Corchorus olitorius Leaf Extract
}

\author{
Kingsley Omeje, Henry Omeje, Arome Odiba*, Ogechukwu Anunobi and Chimere Ukegbu \\ Department of Biochemistry, University of Nigeria, Nsukka, Nigeria
}

*Corresponding author.

\begin{abstract}
Corchorus olitorius is a common vegetable in Nigeria used in making soup and stew. This study determined the effect of the ethanol extract of $C$. olitorius leaves on the activity of liver function enzymes and lipid profiles in Wistar albino rats. Twenty four (24) Wistar rats weighing between 150-200 g were randomly grouped into four of six animals each. Groups 1-3 rats received $2 \mathrm{ml} \mathrm{50,100} \mathrm{and} 200 \mathrm{mg} / \mathrm{kg}$ b.w. respectively, while the control group also received $2 \mathrm{ml}$ of distilled water orally for the period of the experiment. All animals were sacrificed after experimental period of 28 days. The results showed that the extract significantly $(p=0.05)$ reduced the serum activities of AST, ALT and ALP when compared to the control at all doses tested. Also, the extract significantly reduced the concentration of total cholesterol at 50 and $100 \mathrm{mg} / \mathrm{kg}$ b.w. of the ethanol extract of $C$. olitorius and significantly $(p=0.05)$ increased it at $200 \mathrm{mg}$ when compared to the control. A dose dependent significant $(p=0.05)$ increase in the concentration of HDL and triacylglycerol were observed in all groups when compared to the control. The result of this study suggests that the ethanol extract of $C$. olitorius possesses hepatoprotective properties with possible tendency to increase the cholesterol concentrations at high doses.
\end{abstract}

\section{Article Info}

Accepted: 19 May 2016

Available Online: 06 June 2016

Ke y w o r d s

Corchorus olitorius

Hepatoprotective activity

Liver enzymes

Lipid profiles

Leaf extract

\section{Introduction}

Plant materials are central to traditional and medicinal practices and have remained useful sources of new drugs (O'Brien, 2004). Although, orthodox medicinal practice is generally becoming acceptable; alternative health care is still relied on all over the world (O'Brien, 2004). In the developing countries of the world, traditional herbal medicine is often used side by side with Western medicine with herbal medicine taking the upper hand when the cost of Western medicine is beyond reach (Busia, 2005). Currently, there is a renewed and growing interest in the use of plant-based products as spices, vegetables and drugs in the manufacture of more potent drugs (Ogbonnia et al., 2008). Plants have contributed immensely to the wellbeing of humans and animals. In the early days before the introduction of modern drugs, humans used herbs for the management of various diseases through trial and error method (Omeje et al., 2014a). The use of plants for the treatment of different ailments had contributed immensely to the well-being of humans and animals. Plants possess phytochemicals that exert some of the medicinal and pharmacology qualities when they are ingested such phytochemicals include alkaloids, flavonoids, saponins, phenol compounds, steroids and proteins (Negem et al., 1980; Omeje et al., 2014b). Corchorus olitorius is a common native vegetable used as spice in many homes in West Africa including Nigeria (Omeje et al., 2014a). The edible shoot and leaves are always eaten and cooked as potherbs. In West Africa, their edible qualities are widely appreciated, where the shoots and leaves are combined in 
soups and stews. It contains high quantity of vitamin A, protein, fibre, calcium, iron, carotene and folic acid (Shashi et al., 2013). The aim of this study was to evaluate the effect of the ethanol extract of $C$. olitorius leaves on the activities of liver function enzymes and lipid profile in Wistar rat.

\section{Materials and methods}

\section{Collection and identification of plant material}

Fresh leaves of $C$. olitorius were bought from Eke-Awka in Awka South L.G.A, Anambra State of Nigeria for the study. The plant sample was identified and authenticated by Prof. C.O. Okeke, a taxonomist in the Department of Botany, Nnamdi Azikiwe University, Awka.

\section{Preparation of plant material}

The leaves were dried at room temperature $\left(29 \pm 2^{\circ} \mathrm{C}\right)$ for four days and pulverized with an electric blender. The powdered plant material that weighed $450 \mathrm{~g}$ was soaked in 1 litre of $70 \%$ ethanol for $48 \mathrm{hrs}$. The extract was filtered and concentrated by indirect heating using water bath. The extract yield was $3.46 \%$ of the dried pulverized sample of the leaves.

\section{Preparation of the animal samples}

Twenty-four adult Wistar albino rats (150-200 g) were obtained from the Animal House of Safety Diagnostic and Research laboratory, Nsukka and used for the study. They were kept in the animal house at a temperature of $29 \pm 2^{\circ} \mathrm{C}$. They were fed with commercial rat chow (Top feed grower's mash) with nutrient composition.

The animals were divided into four groups of six rats each. They received the ethanol extract orally once every day, for the period of twenty eight days as follows:

Group I (Six rats) received $2 \mathrm{ml}$ of distilled water $/ \mathrm{kg}$ body weight (b.w.) was used as negative control.

Group II (Six rats) received $50 \mathrm{mg} / \mathrm{kg}$ b.w. of ethanol extract.

Group III (Six rats) received $100 \mathrm{mg} / \mathrm{kg}$ b.w. of the ethanol extract.

Group IV (Six rats) received $200 \mathrm{mg} / \mathrm{kg}$ b.w. of the ethanol extract.

\section{Sample collection}

Blood sample was collected from the retro-bulbar plexus of the medial canthus of the eye of rats. A microhematocrit tube was carefully inserted into the medial canthus of the eye to puncture the retro-bulbar plexus and thus enable outflow of $3 \mathrm{ml}$ of blood into a clean glass test tube. The blood sample was kept at room temperature for 30min. to clot. Afterwards, the test tube containing the clotted blood sample was centrifuged at 3000rpm for ten minutes using a table centrifuge, to enable a complete separation of the serum from the clotted blood. The clear serum supernatant was then carefully aspirated with syringe and needle and stored in a clean sample bottle for the clinical chemistry determinations.

\section{Assay of alanine aminotransferase (ALT) activity}

Alanine aminotransferase activity was determined by the Reitman-Frankel (1957) colorimetric method for in vitro determination.

\section{Assay of serum alkaline phosphatase (ALP) activity}

Serum alkaline phosphatase activity was determined using Phenolphthalein monophosphate method of Klein et al. (1960) and Babson et al. (1996).

\section{Assay of aspartate aminotransferase (AST) activity}

Aspartate aminotransferase (AST) activity was determined by the Reitman-Frankel colorimetric method for in-vitro determination (Reitman and Frankel, 1957).

Total cholesterol concentration was determined by the method of Fredrick et al. (1967). HDL concentration was determined according to the method of Albers et al. (1978). Triacylglycerol concentration was estimated according to the method of Jacobs and Demark (1960).

\section{Statistical analysis}

The results were expressed as mean $\pm \mathrm{SD}$ and test of statistical significance was carried out using one-way analysis of variance (ANOVA). The means were separated using Duncan multiple Test. Differences were considered significant at $p=0.05$. The statistical packaged used was the statistical package for social sciences (SPSS), version 17. 


\section{Results and discussion}

The nutrient contents of the leaves of $C$. olitorius are given in Table 1. The effects of ethanol leaves extract of Corchorus olitorius on the activity of liver function enzymes (ALP, AST, ALT) in rats administered with 50, 100 , and $200 \mathrm{mg} / \mathrm{kg}$ body weight of the extract are shown in Figs. 1, 2 and 3 respectively. Serum alanine aminotransferase (ALT) is known to increase when there is liver disease and it has been used as a tool for measuring hepatic necrosis (Duncan et al., 2006). Hence, the observed decrease in serum ALT suggests that the extract contain some bio active agents that have the ability to protect hepatic tissue at 50, 100 and $200 \mathrm{mg} / \mathrm{kg}$ b.w. Similarly, aspartate aminotransferase (AST) is another important liver enzyme, though not specific to liver alone, it is predominantly localized within the cells of the gills, kidney, muscle and liver parenchymal cells with an increase in serum AST signifying acute liver damage or liver cytolysis (Dasofunjo et al., 2013). Therefore, the significant decrease $(p=0.05)$ of this study suggests that the ethanol extract has the ability to maintain the integrity of the animal liver. ALP is frequently used to access the plasma integrity of plasma membrane (Novick et al., 2006). Hence, the results of our study suggest that the extract contained no inherent or produced no secondary metabolite that negatively interacted with the liver cells, hence the decreased in the enzyme activity obtained. Similar work done by Adedosu et al. (2015) on the effect of $C$. olitorius on some antioxidants and biochemical indices in sodium arsenate exposed rat indicated that the extract can remedy damaged liver.

Table 1. Nutrient composition of $C$. olitorius leaves.

\begin{tabular}{ll}
\hline Nutrient & $(\boldsymbol{\%})$ \\
\hline Crude protein & 16.0 \\
Minimum energy & 11.1 \\
Calcium & 1.0 \\
Phosphorus & 0.7 \\
\hline
\end{tabular}

Musa and Ogbadoyi (2012) reported a rise in the activity of liver enzymes, which they attributed to the presence of some anti-nutrients in the leaves of $C$. olitorius. Another study has shown that the ingestion of $C$. olitorius can induce or aggravate hepatotoxicity and may play a role in liver damage (Iweala and Okedoyin, 2014). This is in contrast with the result of this study. Here, the enzyme activity results suggested that the ethanol extract of $C$. olitorius has hepato-protective effect. It could be attributed that the solvent (ethanol) used during the extraction process destroyed the anti-nutrients that damage the membrane of the organ.

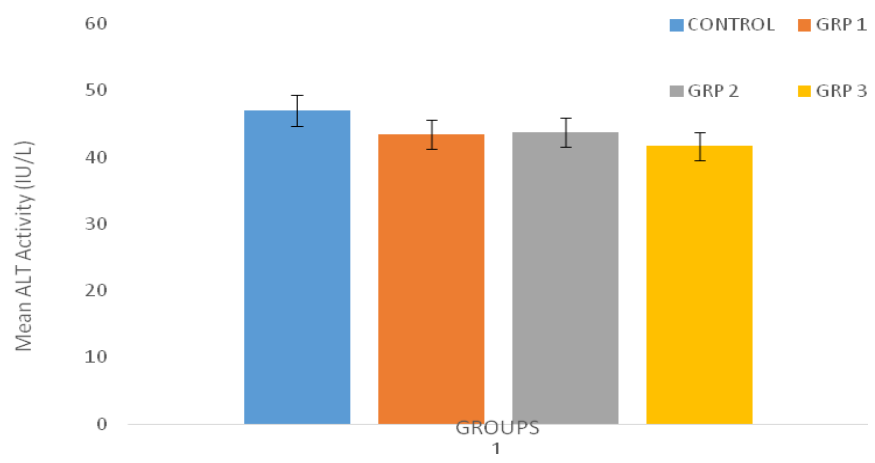

Fig. 1: Effect of ethanol leaves extract of Corchorus olitorius on serum ALT activity in rats (Control $=2 \mathrm{ml}$ of distilled water $/ \mathrm{kg}$ body weight; Group $1=50 \mathrm{mg} / \mathrm{kg}$ b.w. of $C$. olitorius extract; Group $2=100 \mathrm{mg} / \mathrm{kg}$ b.w. of $C$. olitorius extract; Group 3=200 mg/kg b.w. of C. olitorius extract).

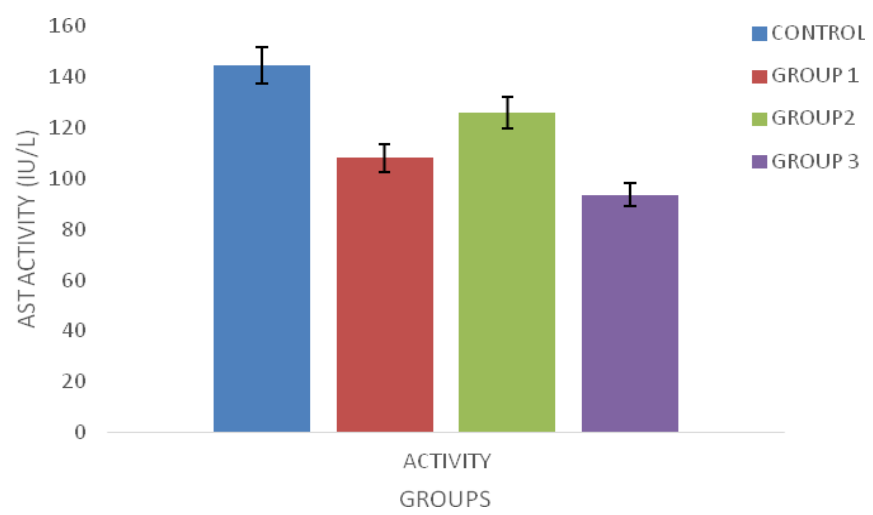

Fig. 2: Effect of ethanol leaves extract of Corchorus olitorius on serum AST activity in rats (Control $=2 \mathrm{ml}$ of distilled water $/ \mathrm{kg}$ body weight; Group $1=50 \mathrm{mg} / \mathrm{kg}$ b.w. of $C$. olitorius extract; Group $2=100 \mathrm{mg} / \mathrm{kg}$ b.w. of $C$. olitorius extract; Group 3=200 mg/kg b.w. of C. olitorius extract).

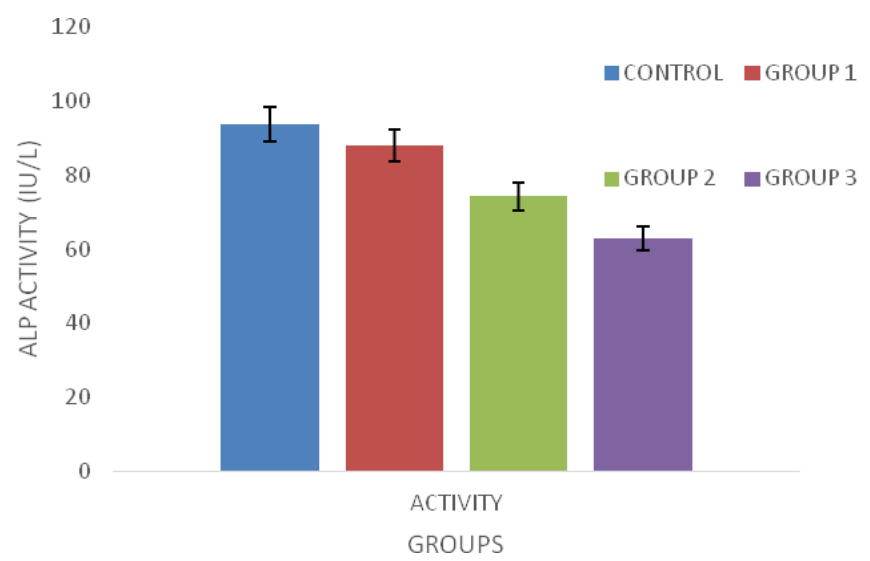

Fig. 3: Effect of ethanol leaves extract of Corchorus olitorius on serum ALP activity in rats. (Control $=2 \mathrm{ml}$ of distilled water $/ \mathrm{kg}$ body weight; Group $1=50 \mathrm{mg} / \mathrm{kg}$ b.w. of $C$. olitorius extract; Group $2=100 \mathrm{mg} / \mathrm{kg}$ b.w. of $C$. olitorius extract; Group 3=200 mg/kg b.w. of C. olitorius extract). 
Table 2. Effect of the ethanol extract of $C$. olitorius leaves on serum lipids of rats.

\begin{tabular}{lllll}
\hline Types of lipid & Control & $\mathbf{5 0 m g / k g ~ b . w . ~}$ & $\mathbf{1 0 0 m g / k g ~ b . w . ~}$ & $\mathbf{2 0 0 m g / k g ~ b . w . ~}$ \\
\hline Total cholesterol $(\mathrm{mmol} / \mathrm{l})$ & $1.96 \pm 0.10$ & $1.46 \pm 0.05$ & $1.66 \pm 0.11$ & $2.06 \pm 0.07$ \\
HDL concentration $(\mathrm{mmol} / \mathrm{l})$ & $0.79 \pm 0.04$ & $0.84 \pm 0.13$ & $0.89 \pm 0.08$ & $0.93 \pm 0.15$ \\
TAG concentration $(\mathrm{mmol} / \mathrm{l})$ & $0.83 \pm 0.04$ & $0.92 \pm 0.10$ & $1.06 \pm 0.10$ & $1.43 \pm 0.08$ \\
\hline
\end{tabular}

Table 2 shows the effect of oral administration of ethanol extract of $C$. olitorius leaves on some serum lipids (total cholesterol, high density lipoprotein (HDL) and triacylglycerol (TAG). The total cholesterol concentration reduced significantly $(p<0.05)$ by the ethanol extract at 50 and $100 \mathrm{mg} / \mathrm{kg} \mathrm{b.w.,} \mathrm{when}$ compared to the control. This result is in agreement with the work of Adedosu et al. (2015). At $200 \mathrm{mg} / \mathrm{kg}$ b.w. of the extract, there was a significant $(p>0.05)$ increase in the concentration of the total cholesterol $(2.06 \pm 0.07$ $\mathrm{mmol} / \mathrm{l})$. Also, a successive increase was noticed in the HDL-concentration in a dose dependent manner. Generally, there was a significant increase in all doses when compared to the control as shown in Table 2. The ability of the extract to reduce the total cholesterol level at doses of 50 and $100 \mathrm{mg} / \mathrm{kg}$ b.w. is beneficial. This property is attributed to the presence of some important phytochemicals (Lim et al., 2007). There was an increase in the concentration of cholesterol $(2.06 \pm 0.07 \mathrm{mmol} / \mathrm{l})$ at $200 \mathrm{mg} / \mathrm{kg} \mathrm{b}$.w. This suggests that excessive ingestion of this vegetable may predispose one to cholesterol related illnesses. Also, the extract significantly increased $(p=0.05)$ the concentration of triacylglycerol when compared to the control in all groups analyzed.

\section{Conclusion}

The effect of ethanol extract of $C$. olitorius on liver enzymes suggests that it protected the integrity of the liver cells. Also, it reduced the concentration of total cholesterol at 50 and $100 \mathrm{mg} / \mathrm{kg} \mathrm{b.w}$. with an increase at $200 \mathrm{mg} / \mathrm{kg} \mathrm{b}$.w. The result of this study suggests that the ethanol extract of $C$. olitorius possesses hepatoprotective properties with possible tendency to increase the cholesterol concentrations when ingested at high quantities.

\section{Conflict of interest statement}

Authors declare that they have no conflict of interest.

\section{Acknowledgement}

Authors wish to acknowledge the Department of Biochemistry, University of Nigeria, for their help through the supply of equipment for this research.

\section{References}

Adedosu, O. T., Akanni, O. E., Afolabi, O. K., Adedeji, L. A., 2015. Effects of Corchorus olitorius extract on certain antioxidants and biochemical indices in sodium arsenite exposed rats. Am. J. Phytomed. Clin. Therap. 3(3), 245256.

Albers, J. J., Warmick, G. R., Cheung, M. C., 1978. Quantification of high-density lipoproteins. Lipids. 3, 926932.

Babson, A. L., Greeley, S. J., Coleman, C. M., Philips, G. E., 1996. Phenolphthalein monophosphate as a substrate for serum alkaline phosphatase. Clin. Chem. 12(18), 482-490.

Busia, K., 2005. Medical provision in Africa- past and present. Photother. Res. 19, 919-923.

Dasofunjo, K., Nwodo, O. F. C., Yakubu, O. E., Ejoba, R., Ukpanukpong, R. U., Ipav, S. S., Ugwu, M. N., Okafor, A. I, Girgi, S. L., 2013. Hepatoprotective effect of Piliostigma thonningii leaves on male Wistar albino rats. Asian J. Plant Sci. Res. 3(4), 13-17.

Duncan, G. E., Moy, S. S., Lieberman, J. A., Koller, B. H., 2006. Typical and atypical antipsychotic drug effects on locomotor hyperactivity and deficits in sensorimotor gating in a genetic model of NMDA receptor hypofunction. Pharmacol. Biochem. Behav. 10(85), 481491.

Fredrick, D. S., Levy, R. I., Lees, R. S., 1967. Fat transport lipoprotein: An integrated approach to mechanisms and disorders. N. Engl. J. Med. 276, 148-156.

Iweala, E. E. J., Okedoyin, A. G., 2014. Effect of consumption of Corchorus olitorius L., in carbon tetrachloride induced liver damage in male Wistar rats. Am. J. Biochem. Mol. Biol. 4(4), 143-154.

Jacobs, N. J., Demark, P. J. 1960. The purification and properties of the alpha-glycerophosphate-oxidizing enzyme of Streptococcus faecalis 10C1. Arch. Biochem. Biophys. 38, 250-255.

Klein, B., Read, P.A., Babson, A.L., 1960. Rapid method for the quantitative determination of serum alkaline phosphatase. Clin. Chem. 6, 269-275.

Lim, Y. Y., Lim, T. T., Tee, J. J., 2007. Antioxidant property of several tropical fruits: A comparative study. Food Chem. 103, 1003-1008.

Musa, A., Ogbadoyi, E. O., 2012. Effect of cooking and sun drying on micronutrients, anti- nutrients and toxic substances in Corchorus olitorius (Jute mallow). J. Nutr. Food Sci. 2, 14.

Negem, S., EI-Shabrawy, O., Arbid, M., Radwan, A. S., 1980. Toxicological study of the different organs of Corchorus olitorius plant with special reference to the cardiac glycosides content. Zeit Sc. Ernahrungsw. 19(1), 28-32. 
Novick, A. C., Jones, J. S., Gill, I. S., Klein, E. A., Rackley, R., Ross, R. H., 2006. Operative Urology at the Cleveland Clinic. Humana Press, Totown, N.J.

O'Brien, K., 2004. Complementary and alternative medicine: the move into mainstream health care. Clin. Exp. Optomol. 87, 193-194.

Ogbonnia, S., Adekunle, A. A., Bosa, M. K., Enwuru, V. N., 2008. Evaluation of acute and subacute toxicity of Alstonia congensis Engler (Apocynaceae) bark and Xylopia aethiopica (Dunal) A. Rich (Annonaceae) fruits mixtures used in the treatment of diabetes. Afr. J. Biotechnol. 7(6), 701-705.

Omeje, K. O., Odo, C. E., Ejembi, D. O., Ossai, N. I., Eneje, V. O., Chukwuka, R. S., Omeje, H. C., 2014a. The effects of ethanol extract of Corchorus olitorius leaves on haematological indices of Wistar albino rat. Acad. J. Food Res. 2(1), 7-9.

Omeje, K. O., Odiba, A. S., Ejembi, D. O., Chukwuka, R. S., 2014b. Platelet aggregation effect of Corchorus olitorius extract as an index of managing blood clotting disorders. IOSR-J. Dental Med. Sci. 13(10), 58-60.

Shashi, B. C., Hariom K. S., Pran, G. K., Anil K., Amit, R. S., Pranab, H., Bikas, S. M., 2013. Nutritional profile of cultivated and wild jute (Corchorus) species. Aus. J. Crop Sci. 7(13), 1973-1982.

Reitman, S., Frankel, S. A., 1957. Colorimetric method for determination of serum glutamic -oxaloacaetic and glutamic-pyruvic transaminases. Am. J. Clin. Pathol. 28, 56-62.

\section{How to cite this article:}

Omeje, K., Omeje, H., Odiba, A., Anunobi, O., Ukegbu, C., 2016. Liver enzymes and lipid activities in response to Corchorus olitorius leaf extract. Int. J. Curr. Res. Biosci. Plant Biol. 3(6), 45-49.

doi: http://dx.doi.org/10.20546/ijcrbp.2016.306.007 